\title{
Sustainability in agri-food systems: transformative trajectories toward the post-Anthropocene
}

\author{
Markus Keck ${ }^{1}$
}

Published online: 12 April 2021

(c) The Author(s) 2021

\section{Background}

Current agri-food systems cause severe environmental, socioeconomic, and health-related problems. The ways how food and other agricultural goods are produced, marketed, consumed, and disposed of are leading drivers of environmental degradation and climate change (Campbell et al. 2017; Weis 2010). At the same time, large-scale profit-oriented agri-food corporations exploit economically underprivileged workers and thus help intensifying socioeconomic divides and deprivation in our societies, accompanied by increasing rates of malnutrition and ill-health through unbalanced diets (Gordon et al. 2017; Lindgren et al. 2018; Winson and Choi 2017). Against this background, business as usual is no longer an option. Change is needed, and this change must necessarily be based on bold theoretical thinking and practical economic transformation.

This Special Feature gathers scholars from a wide range of academic disciplines and provides them a space for presenting innovative empirical case studies and critical theoretical reflections that together help rethinking how sustainability in agri-food systems can be achieved. The essential idea is to illustrate possibilities of creating agri-food systems that foster biodiversity, provide involved practitioners with prestigious jobs and decent income, and enable consumers to access healthy diets at reasonable prices while reducing society's material and energy footprint. The presented papers will advance existing conceptual approaches, debate innovative practical solutions and stimulate new forms of thinking and doing to extend the debate about sustainability and to open up routes out of the Anthropocene as "human dominated geological epoch" (Lewis and Maslin 2015: 171).

Markus Keck

markus.keck@uni-koeln.de

1 Global South Studies Center, University of Cologne, Classen-Kappelmann-Str. 24, 50931 Cologne, Germany

\section{Aims and scope}

We start from the proposition to understand the Anthropocene as both a set of physiological phenomena and an existential crisis of modernity (Reisman and Fairbairn 2020). On the one hand, we are aware of the rapid rise in water use, fertilizer contamination, deforestation, and greenhouse gas emissions to be increasing the risk that self-reinforcing feedbacks push the Earth System toward a planetary threshold that, if crossed, could prevent the stabilization of the climate at intermediate temperature rises and lead to a much higher global average temperature than in any interglacial in the past 1.2 million years (Steffen et al. 2007, 2015, 2018). On the other hand, we understand that attributing global change to a universalized human "Anthropos" risks ignoring the role of structural inequalities along the lines of class, race, gender, and geography in producing these changes (Malm and Hornborg 2014). Singling out a species as irreversibly dominant might inhibit political action by naturalizing ecological crises, normalizing narratives of control as progress, institutionalizing human mastery, and reifying a false division between humans and the biophysical world of which they are a part (Moore 2017; Simpson 2020; Swyngedouw and Ernstson 2018). Against this background, we see the need to examine existing socio-technical imaginaries of how to solve the challenges of the Anthropocene (Jasanoff 2015; Nightingale et al. 2019) and to reflect upon possible other futures (Gibson-Graham 2008; Koretskaya and Feola 2020) to re-politicize future making and to open it up to public contestation (Knappe et al. 2019).

This special feature consists of papers that address at least one of the following questions:

1. How can we attain to a more context-sensitive understanding of socio-technical regime shifts and sustainability transitions (Geels 2018), which takes the individuality of particular niche-regime interactions into account and accentuates the agency of involved actors 
as well as underlying power relations (Bui et al. 2016; Feola 2020; Ingram 2018)?

2. How can we put the concept of circular economy (Ellen MacArthur Foundation 2013; Kirchherr et al. 2017) into action and what knowledge gaps remain to be bridged before we can think of "closing material loops" to ultimately decouple agri-food systems from finite resource consumption (Giampietro 2019; Koppelmäki et al. 2021; Zink and Geyer 2017)?

3. How can we practically gain from approaches that provide more fundamental critique of current agri-food systems, such as the concept of degrowth, which explores alternative forms of organizing economies beyond growth and capital accumulation (Demaria et al. 2019; Gerber 2020; Kallis et al. 2018), or more-than-humanism, which invites us to embracing the idea of conviviality and to horizontalizing the relations between humans, biota, and abiota (Beacham 2018; Krzywoszynska 2019; Sarmiento 2017)?

4. How can specific methods to quantitatively assess production and consumption systems, such as life cycle assessments (Cucurachi et al. 2019; Green et al. 2020; Notarnicola et al. 2017), be turned into practical use for building more sustainable agri-food systems?

To participate in the planned special feature, please send an abstract of maximum 300 words until Friday, 2 April 2021 to markus.keck@ uni-koeln.de. Deadline for the submission of final papers is Friday, 30 July 2021. The special feature is scheduled to be published in issue 2 or 3 in 2022. Prior publication of accepted articles as Online First is possible.

Funding Open Access funding enabled and organized by Projekt DEAL

Open Access This article is licensed under a Creative Commons Attribution 4.0 International License, which permits use, sharing, adaptation, distribution and reproduction in any medium or format, as long as you give appropriate credit to the original author(s) and the source, provide a link to the Creative Commons licence, and indicate if changes were made. The images or other third party material in this article are included in the article's Creative Commons licence, unless indicated otherwise in a credit line to the material. If material is not included in the article's Creative Commons licence and your intended use is not permitted by statutory regulation or exceeds the permitted use, you will need to obtain permission directly from the copyright holder. To view a copy of this licence, visit http://creativecommons.org/licenses/by/4.0/.

\section{References}

Beacham J (2018) Organising food differently: towards a morethan-human ethics of care for the Anthropocene. Organization 25(4):533-549. https://doi.org/10.1177/1350508418777893
Bui S, Cardona A, Lamine C, Cerf M (2016) Sustainability transitions: Insights on processes of niche-regime interaction and regime reconfiguration in agri-food systems. J Rural Stud 48:92-103. https://doi.org/10.1016/j.jrurstud.2016.10.003

Campbell BM, Beare DJ, Bennett EM, Hall-Spencer JM, Ingram JSI, Jaramillo F, Ortiz R, Ramankutty N, Sayer JA, Shindell D (2017) Agriculture production as a major driver of the Earth system exceeding planetary boundaries. Ecol Soc 22(4):8. https://doi. org/10.5751/ES-09595-220408

Cucurachi S, Scherer L, Guinée J, Tukker A (2019) Life cycle assessment of food systems. One Earth 1(3):292-297. https://doi.org/ 10.1016/j.oneear.2019.10.014

Demaria F, Kallis G, Bakker K (2019) Geographies of degrowth: Nowtopias, resurgences and the decolonization of imaginaries and places. Environ Plan E Nat Space 2(3):431-450. https://doi. org/10.1177/2514848619869689

Ellen MacArthur Foundation (2013) Towards the circular economy: economic and business rationale for an accelerated transition. https://www.ellenmacarthurfoundation.org/assets/downloads/ publications/Ellen-MacArthur-Foundation-Towards-the-Circu lar-Economy-vol.1.pdf. Accessed 15 Mar 2021

Feola G (2020) Capitalism in sustainability transitions research: time for a critical turn? Environ Innov Soc Trans 35:241-250. https:// doi.org/10.1016/j.eist.2019.02.005

Geels FW (2018) Socio-technical transitions to sustainability. In: European Environment Agency (ed) Perspectives on transitions to sustainability. EEA Report. Publications office of the European Union, Luxembourg, pp 45-69

Gerber J-F (2020) Degrowth and critical agrarian studies. J Peasant Stud 47(2):235-264. https://doi.org/10.1080/03066150.2019. 1695601

Giampietro M (2019) On the circular bioeconomy and decoupling: Implications for sustainable growth. Ecol Econ 162:143-156. https://doi.org/10.1016/j.ecolecon.2019.05.001

Gibson-Graham JK (2008) Diverse economies: performative practices for 'other worlds.' Prog Hum Geogr 32(5):613-632. https://doi. org/10.1177/0309132508090821

Gordon LJ, Bignet V, Crona B, Henriksson PJG, Van Holt T, Jonell M, Lindahl T, Troell M, Barthel S, Deutsch L, Folke C, Haider LJ, Rockström J, Queiroz C (2017) Rewiring food systems to enhance human health and biosphere stewardship. Environ Res Lett 12:100201. https://doi.org/10.1088/1748-9326/aa81dc

Green A, Nemecek T, Chaudhary A, Mathys A (2020) Assessing nutritional, health, and environmental sustainability dimensions of agri-food production. Glob Food Secur 26:100406. https://doi. org/10.1016/j.gfs.2020.100406

Ingram J (2018) Agricultural transition: Niche and regime knowledge systems' boundary dynamics. Environ Innov Soc Trans 26:117135. https://doi.org/10.1016/j.eist.2017.05.001

Jasanoff S (2015) Future imperfect: science, technology and the imaginations of modernity. In: Jasanoff S, Kim SH (eds) Dreamscapes of modernity: sociotechnical imaginaries and the fabrication of power. University of Chicago Press, London, pp 1-33

Kallis G, Kostakis V, Lange S, Muraca B, Paulson S, Schmelzer M (2018) Research on degrowth. Annu Rev Environ Resour 43(1):291-316. https://doi.org/10.1146/annurev-envir on-102017-025941

Kirchherr J, Reike D, Hekkert M (2017) Conceptualizing the circular economy: an analysis of 114 definitions. Resour Conserv Recycl 127:221-232

Knappe H, Holfelder A-K, Löw Beer D, Nanz P (2019) The politics of making and unmaking (sustainable) futures: introduction to the special feature. Sustain Sci 14(4):891-898. https://doi.org/10. 1007/s11625-019-00704-w

Koppelmäki K, Helenius J, Schulte RPO (2021) Nested circularity in food systems: a Nordic case study on connecting biomass, nutrient 
and energy flows from field scale to continent. Resour Conserv Recycl 164:105218. https://doi.org/10.1016/j.resconrec.2020. 105218

Koretskaya O, Feola G (2020) A framework for recognizing diversity beyond capitalism in agri-food systems. J Rural Stud 80:302-313. https://doi.org/10.1016/j.jrurstud.2020.10.002

Krzywoszynska A (2019) Caring for soil life in the Anthropocene: the role of attentiveness in more-than-human ethics. Trans Inst $\mathrm{Br}$ Geogr 44(4):661-675. https://doi.org/10.1111/tran.12293

Lewis SL, Maslin MA (2015) Defining the Anthropocene. Nature 519(7542):171-180. https://doi.org/10.1038/nature14258

Lindgren E, Harris F, Dangour AD, Gasparatos A, Hiramatsu M, Javadi F, Loken B, Murakami T, Scheelbeek P, Haines A (2018) Sustainable food systems - a health perspective. Sustain Sci 13:15051517. https://doi.org/10.1007/s11625-018-0586-x

Malm A, Hornborg A (2014) The geology of mankind? A critique of the Anthropocene narrative. Anthr Rev 1(1):62-69. https://doi. org/10.1177/2053019613516291

Moore JW (2017) The Capitalocene, part I: on the nature and origins of our ecological crisis. J Peasant Stud 44(3):594-630. https://doi. org/10.1080/03066150.2016.1235036

Nightingale AJ, Eriksen S, Taylor M, Forsyth T, Pelling M, Newsham A, Boyd E, Brown K, Harvey B, Jones L, Bezner Kerr R, Mehta L, Naess LO, Ockwell D, Scoones I, Tanner T, Whitfield S (2019) Beyond technical fixes: climate solutions and the great derangement. Clim Dev 12(4):343-352. https://doi.org/10.1080/17565 529.2019.1624495

Notarnicola B, Sala S, Anton A, McLaren SJ, Saouter E, Sonesson U (2017) The role of life cycle assessment in supporting sustainable agri-food systems: a review of the challenges. J Clean Prod 140(2):399-409. https://doi.org/10.1016/j.jclepro.2016.06.071

Reisman E, Fairbairn M (2020) Agri-food systems and the Anthropocene. Ann Am Assoc Geogr Online First. https://doi.org/10.1080/ 24694452.2020 .1828025

Sarmiento ER (2017) Synergies in alternative food network research: embodiment, diverse economies, and more-than-human food geographies. Agric Hum Values 34:485-497. https://doi.org/10. 1007/s10460-016-9753-9

Simpson M (2020) The Anthropocene as colonial discourse. Environ Plan D Soc Space 38(1):53-71. https://doi.org/10.1177/02637 75818764679

Steffen W, Crutzen PJ, McNeill JR (2007) The Anthropocene: are humans now overwhelming the great forces of nature? AMBIO J Hum Environ 36(8):614-621. https://doi.org/10.1579/00447447(2007)36[614:taahno]2.0.co;2

Steffen W, Broadgate W, Deutsch L, Gaffney O, Ludwig C (2015) The trajectory of the Anthropocene: the great acceleration. Anthr Rev 2(1):81-98. https://doi.org/10.1177/2053019614564785

Steffen W, Rockström J, Richardson K, Lentond TM, Folke C, Liverman D, Summerhayes CP, Barnosky AD, Cornell SE, Crucifix M, Donges JF, Fetzer I, Lade SJ, Scheffer M, Winkelmann R, Schellnhuber HJ (2018) Trajectories of the earth system in the Anthropocene. Proc Natl Acad Sci 115(33):8252-8259. https:// doi.org/10.1073/pnas.1810141115

Swyngedouw E, Ernstson H (2018) Interrupting the AnthropoobScene: immuno-biopolitics and depoliticizing ontologies in the Anthropocene. Theory Cult Soc 35(6):3-30. https://doi.org/ $10.1177 / 0263276418757314$

Weis T (2010) The accelerating biophysical contradictions of industrial capitalist agriculture. J Agrar Change 10(3):315-341. https://doi. org/10.1111/j.1471-0366.2010.00273.x

Winson A, Choi JY (2017) Dietary regimes and the nutrition transition: bridging disciplinary domains. Agric Hum Values 34(3):559-572. https://doi.org/10.1007/s10460-016-9746-8

Zink T, Geyer R (2017) Circular economy rebound. J Ind Ecol 21(3):593-602. https://doi.org/10.1111/jiec.12545

Publisher's Note Springer Nature remains neutral with regard to jurisdictional claims in published maps and institutional affiliations. 